\title{
Characterization of the Clay Collected in the Locality of Dolisie in Congo-Brazzaville
}

\author{
Rarahu Nursie Mboho Oba', Grace Mazel Ifo, 1,2, Erman Eloge Nzaba Madila1,3, \\ Flora Zita Mpissi Diamouangana, ${ }^{1,4}$, Thierry Vila1, Mozalin Paul Foutou' ${ }^{1}$, Joseph-Marie Moutou ${ }^{1}$ \\ ${ }^{1}$ Laboratoire de Chimie Minérale Appliquée (LACMA), Faculté des Sciences et Techniques, Université Marien Ngouabi, \\ Brazzaville, Congo Brazzaville \\ ${ }^{2}$ Faculté des Sciences et Techniques, Université Marien Ngouabi, Brazzaville, Congo Brazzaville \\ ${ }^{3}$ Département de Chimie, Biochimie et Physique and Institut de Recherche sur l'Hydrogène, Université du Québec à \\ Trois-Rivières, Trois-Rivières, Québec, Canada \\ ${ }^{4}$ Ecole Normale Supérieure, Université Marien Ngouabi, Brazzaville, Congo Brazzaville \\ Email: florajullie@gmail.com
}

How to cite this paper: Oba, R.N.M., Ifo, G.M., Madila, E.E.N., Diamouangana, F.Z.M., Vila, T., Foutou, M.P. and Moutou, J.-M. (2022) Characterization of the Clay Collected in the Locality of Dolisie in Congo-Brazzaville. Journal of Minerals and Materials Characterization and Engineering, 10, 93-105.

https://doi.org/10.4236/jmmce.2022.102007

Received: November 4, 2021

Accepted: February 8, 2022

Published: February 11, 2022

Copyright $\odot 2022$ by author(s) and Scientific Research Publishing Inc. This work is licensed under the Creative Commons Attribution International License (CC BY 4.0).

http://creativecommons.org/licenses/by/4.0/

\section{(c) (i) Open Access}

\begin{abstract}
This work aims at the characterization of the clay of the locality of Dolisie for its valorization. The mineralogical analysis was determined by the following techniques (DRX, IR, ATG and ATD), chemical analysis was determined by ICP-AES, CEC was assessed by the Metson method. The geothermal properties were determined by the granulometric analysis of the clay soil and allowed us to position the Dolisie clay in the texture triangle, the landings limits obtained allowed to place the Dolisie clay in the abacus of Casagrande and on the workability map of Bain and Highy. Chemical analysis showed that silica alumina as well as iron oxides are the major constituents in Dolisie clay The mineralogical balance showed that kaolinite and illite have similar percentages which are (20.51\%) kaolinite, (28.08) illites. This leads us to believe that kaolinite is not the dominant mineral and the IR spectrum shows that kaolinite is poorly crystallized.
\end{abstract}

\section{Keywords}

Clay, Characterization, Mineralogy, Valuation

\section{Introduction}

Clays are natural minerals that have been used by humans for millennium due to their abundance. In recent years, particular interest has been given to the study of clays by numerous laboratories around the world, justified by the importance of the specific surface developed by this material, the presence of electric charges 
on the surface, the possibility of cation exchange and their remarkable properties which make them suitable for multiple applications [1]: molds for metallurgy, oil extraction, cement manufacturing, agriculture, animal and human food, cosmetic health, stationery, textiles, plastics, construction materials and pharmaceuticals [2]. In the Republic of the Congo, clay is used by the Congolese populations in an artisanal way serving for a large part in the making of pottery, in the realization of various art objects, in the construction of houses, for consumption by pregnant women and other women to eliminate nausea and local people use the clay alone or in combination with plants or leaves to cure certain ailments. The Niari region has enormous unidentified clay potential. Only the characterization of a clay could allow its recovery. It is with this in mind that a research program has been set up for the characterization of various clay materials present in the Republic of Congo, with a view to their valorization. Several Congolese localities have already been characterized in particular Loutété, Loukoléla, mouyoundzi, Makonongo and londélakayes and many others [3] [4] [5] [6] [7]. Orient Loukoléla in the environment for adsorption of heavy metals. Mouyoundzi, Makonongo and londé-lakayes could be used in ceramics. It is with this in mind that we have chosen to mineralogically and physically characterize the clay soil sampled in the Niari region in order to predict its future use and also to understand why this soil is used by the local population for consumption.

\section{Materials and Methods}

\subsection{Location of the Sampling Site}

The clay soil sample comes from the town of Dolisie, located in the south of the Republic of Congo in the department of N2. Materials and methods.

\subsection{Location of the Sampling Site}

The clay soil sample comes from the town of Dolisie, located in the south of the Republic of Congo in the department of Niari (Figure 1).

\subsection{Experimental Study}

The collected sample was dried for a week in the laboratory at room temperature. It was then ground in a porcelain mortar and sifted through a sieve.

\subsubsection{X-Ray Diffraction X-Ray Diffraction Was Used for the Analysis of the Compounds}

The measurements were recorded on the raw Dolisie sample using a philips brand diffractometer using a copper anticathode $(\lambda=1.54054 \AA)$ at the Bordeaux Condensed Matter Chemistry Institute (ICMCB). The X spectra were obtained under the following operating conditions:

- Temperature: $25^{\circ} \mathrm{C}$

- Angular range: $5^{\circ} \mathrm{C}<2 \theta<80^{\circ} \mathrm{C}$

- The diffractogram was drawn using the full prof software 


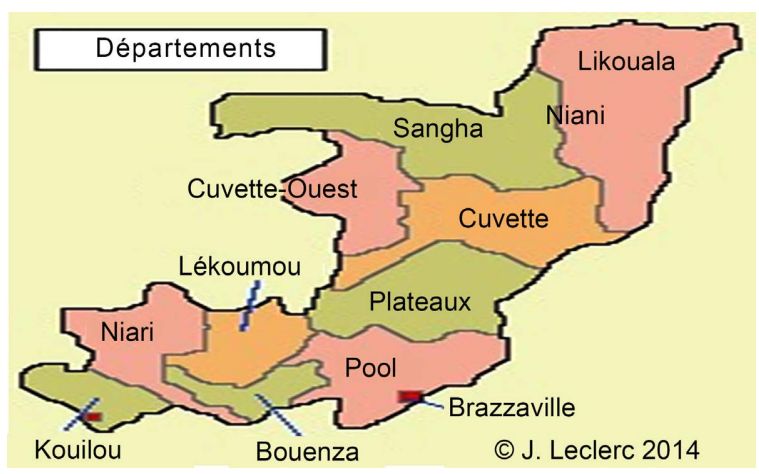

Figure 1. The location map of the sampling site.

\subsubsection{Infrared Spectroscopy Measurements}

The infrared spectroscopy measurements were carried out on a device called Nicolet is 10 Smart FT-IR. Samples were characterized via Attenuated Total Reflection (ATR) by mounting an ATR unit in the spectrometer control compartment. Spectra were recorded in a range between $500 \mathrm{~cm}^{-1}$ and $2500 \mathrm{~cm}^{-1}$ with a $0.5 \mathrm{~cm}^{-1}$ resolution spectrum at the University (UQTR), Duonglab. The IR spectrum was plotted using the origin software.

\subsubsection{Differential Thermal and Gravimetric Analysis}

Thermogravimetric analysis (TGA) of the Dolisie sample was performed by a thermogravimetric analyzer device named Diamond pyris 6000 from perkin-elmer. The measurements were carried out in the temperature range of 30 to $850^{\circ} \mathrm{C}$ using a heating rate of $10^{\circ} \mathrm{C} \cdot \mathrm{Min}^{-1}$. Thermal analysis was performed in alumina crucibles under a nitrogen flow rate of $20.0 \mathrm{ml} \cdot \mathrm{min}^{-1}$ at the University (UQTR), Duonglab. The ATG/ATD curve was obtained using the origin software.

\subsubsection{Chemical Analysis}

The percentage of the elements in oxide was determined by ICP-AES at the petrographic and geochemical research center of Nancy (France) [8].

1) The determination of the CEC

The CEC was determined by the Metson method at the Arras Laboratory in France, consisting of the following steps:

- The sample is first saturated with ammonium ions $\left(\mathrm{NH}_{4}^{+}\right)$by successive percolations of a $1 \mathrm{~mol} / \mathrm{l}$ solution of ammonium acetate $\left(\mathrm{CH}_{3} \mathrm{CO}_{2} \mathrm{NH}_{4}\right)$.

- The buffering capacity of the latter makes it possible to bring the $\mathrm{pH}$ of the medium to around 7, which constitutes one of the essential characteristics of this method. After removing the excess ammonium ions by percolating them with ethyl alcohol, their exchange is then carried out with a $1 \mathrm{~mol} / \mathrm{l}$ solution of sodium chloride. The displaced ammonium ions are assayed by spectrocolometry on the previous solution, once filtered. The concentrations found are converted to $\mathrm{cmol}^{+} / \mathrm{kg}$ (centimoles of positive parkilogram charges of soil). The procedure used is described in the AFNOR NFX31-130 [9] standard. The test is $2.5 \mathrm{~g}$ of ground salt at $2 \mathrm{~mm}$.

2) Organic material 
The percentage of carbon and the percentage of nitrogen which represent the organic matter were determined by the following method: weigh a mass greater than $5 \mathrm{mg}$ of material to be analyzed, so that it is representative, homogenized and steamed for 24 hours at $90^{\circ} \mathrm{C}$.

The resulting sample is introduced into the device using a sample tube port. The helium stream is automatically enriched with a determined amount of pure oxygen, causing flash combustion of the capsule and sample. The combustion gases entrained by the helium stream pass over an oxidation catalyst which transforms them into $\mathrm{CO}_{2}, \mathrm{H}_{2} \mathrm{O}, \mathrm{SO}_{2}, \mathrm{SO}_{3}, \mathrm{NxOy} \ldots$. These gases then pass over a second catalyst (reduced copper) which will reduce the nitrogen oxides to elemental nitrogen, the $\mathrm{SO}_{3}$ to $\mathrm{SO}_{2}$ and trap the excess oxygen. At the exit of the tube, we find in addition to the helium carrier gas, the gases $\mathrm{N}_{2}, \mathrm{SO}_{2}, \mathrm{CO}_{2}$ and $\mathrm{H}_{2} \mathrm{O}$. Non-dosed products are trapped. The gases obtained are then separated in a chromatography column and quantified by a thermal conductivity detector. The signal obtained is amplified and then processed by computers. This method is described by NF ISO 10694 and 13878 at the Aras Soils Laboratory in France [10].

\subsubsection{Particle Size Analysis}

The particle size distribution was determined at the Arras Soil Laboratory (LAS) in France according to standard NF X 31-107 [11]. The finest fractions $(<50 \mu \mathrm{m})$ are determined by means of 3 successive samples (with the so-called Robinson pipette) in a soil suspension during sedimentation. The fine sand fraction is separated by passing through a $50 \mu \mathrm{m}$ sieve and under a stream of water from the suspension after sampling of the fine fractions. The samples and sieving are carried out after destruction of the organic matter by hydrogen peroxide $\left(\mathrm{H}_{2} \mathrm{O}_{2}\right)$ on a test sample of approximately $10 \mathrm{~g}$. The final dispersion is achieved by a short passage to the ultrasons après addition de dispersant $\left[\left(\mathrm{NaPO}_{3}\right)_{6}+\mathrm{Na}_{2} \mathrm{CO}_{3}\right]$ and after having previously separated the coarse sands $(>0.200 \mathrm{~mm})$ by sieving. The weighings after evaporation and drying of the fractions taken with a pipette made it possible to determine the proportions of the different particle size classes.

\subsubsection{The Limits of ATTERBERG}

ATTERBERG limits were determined at the building and public works control office (BCBTP) in CONGO Brazzaville. These limits are calculated by the following formulas:

- Determining the liquidity limit $W_{L}=\frac{P h-P S}{(\text { Pnetsec })}$

- The determination of the limit of plasticity WP

- The deduction of the plasticity index $I_{P}=W_{L}-W_{P}$

\section{Results and Discussion}

\subsection{Diffractograms of the Raw Dolisia Sample}

Figure 2 shows the diffractogram of Dolisie clay. 


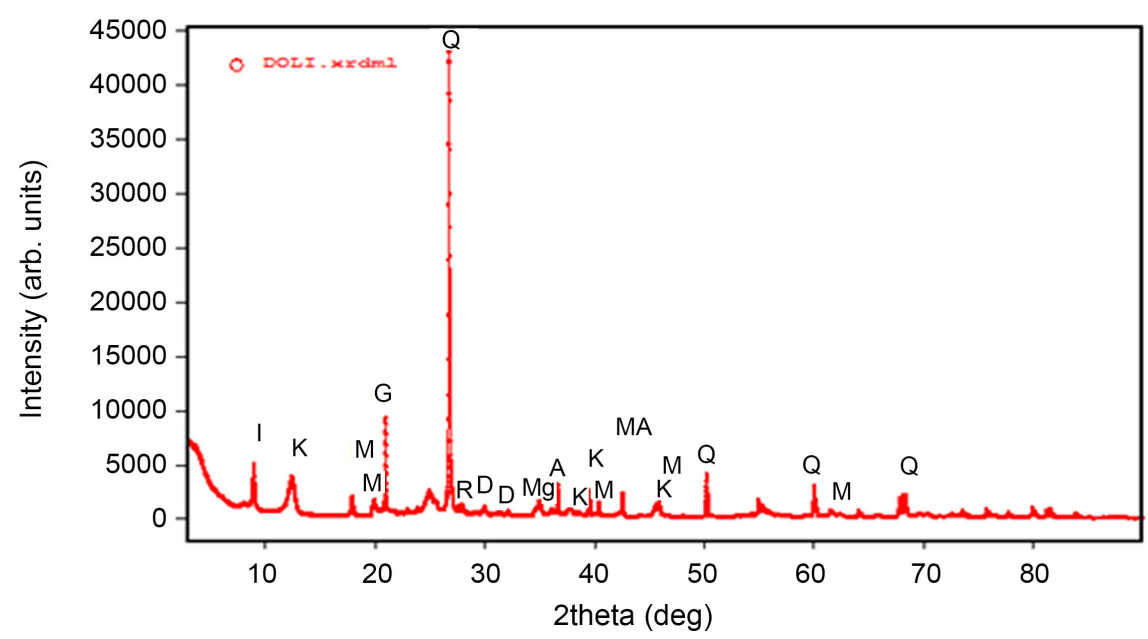

Figure 2. Diffractogram of raw Dolisie clay.

The lattice distances observed in the spectrum of the Dolisie sample are compared to those of kaolinite and quartz. From this comparison, it emerges that the reflections of kaolinite (mineral T-O) are present (7.16; 4.46; 3.57).

Analysis of this spectrum identifies the following species:

- Illite (4.98 $\AA$ ) and muscovite

- Kaolinite (7.16 ̊̊), (4.46 $)(3.57 \AA)$

- Iron oxides (goethite, magnesite and maghemite) (4.18 $\mathrm{A})$

- Anatase and feldspars (3.16 $)$

- Rutile (3.2 $)$, dolomite (2.82 $)$

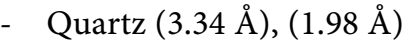

The comparison of the lattice distances of the main peaks of illite and kaolinite leads us not to consider kaolinite as the most abandoned clay mineral.

The considerable abundance of muscovite translates into the importance of the potassium content as reported by chemical analysis. The $\mathrm{SiO}_{2}$ content between $60 \%$ and $80 \%$, that of $\mathrm{Al}_{2} \mathrm{O}_{3}$ between $10 \%$ and $35 \%$ and the sum (Cao + $\mathrm{TiO}_{2}+\mathrm{Fe}_{2} \mathrm{O}_{3}+\mathrm{K}_{2} \mathrm{O}+\mathrm{MgO}+\mathrm{Na}_{2} \mathrm{O}$ ) between $5 \%$ and $30 \%$ allow us to consider that this clay has a low porosity or can be used in the manufacture of sandstone tiles [13]. The high content of $\mathrm{K}_{2} \mathrm{O}$ corresponding to the presence of illites and possibly feldspars associated with that of $\mathrm{Fe}_{2} \mathrm{O}_{3}$, indicates that this clay may, during firing, produce a large quantity of fluxes. The need for fluxes to produce phase change reactions when firing or inducing vitrification is provided by clays containing alkalis or to a lesser extent, rare earths and ferrous ions, and is usually satisfied by the illitic species [14].

\subsection{Infrared Spectroscopies}

Figure 3 represents the infrared spectrum of Dolisie.

The XRD results showed that kaolinite and illite have similar percentages, quartz is associated with them. Kaolinite spectra are generally divided into three domains: the range from $3700 \mathrm{~cm}^{-1}$ to $3100 \mathrm{~cm}^{-1}$, the range from $3100 \mathrm{~cm}^{-1}$ to $1200 \mathrm{~cm}^{-1}$ and the range from $1200 \mathrm{~cm}^{-1}$ to $600 \mathrm{~cm}^{-1}$ [5]. The IR spectrum of 


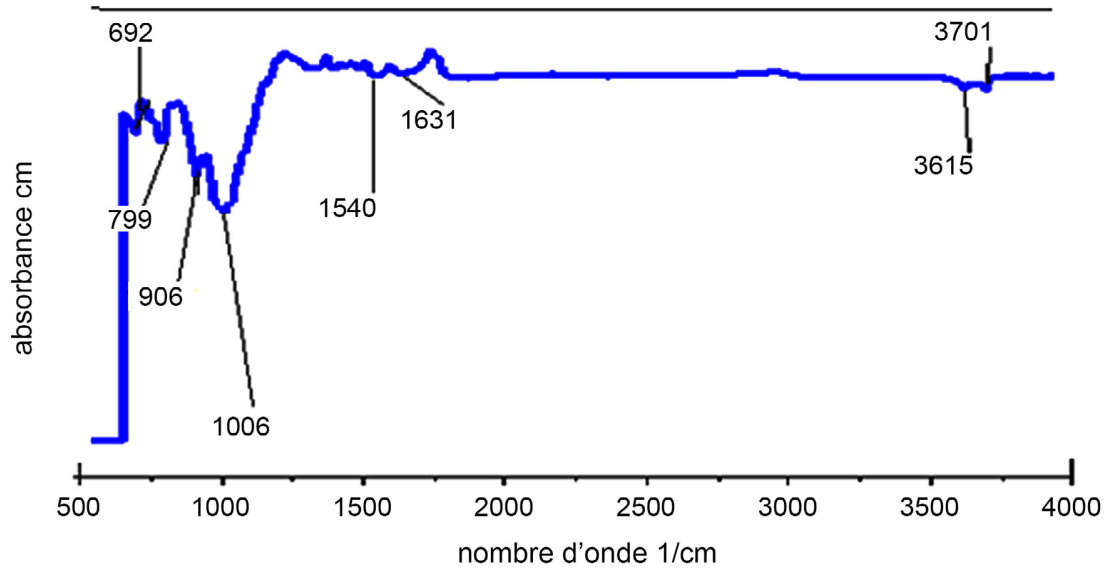

Figure 3. Raw Dolisie infrared spectrum.

Dolisie has two bands $\left(3701 \mathrm{~cm}^{-1}\right.$ and $\left.3615 \mathrm{~cm}^{-1}\right)$, the band at $3701 \mathrm{~cm}^{-1}$ could correspond to the $\mathrm{OH}$ elongation modes. Ray. L. FROST and Philippe De Donato et al by studying the spectrum of kaolinite attributed the frequencies at $3630 \mathrm{~cm}^{-1}$ to the elongation or valence modes of AlO-H [13]. Let us think that the band at $3615 \mathrm{~cm}^{-1}$ corresponds to the vibrations of valence Al-OH.

The presence of quartz in kaolinite is manifested by the Si-O elongation band at $798 \mathrm{~cm}^{-1}$ and by the Si-O deformation band at $696 \mathrm{~cm}^{-1}$ [5]. The band at 799 $\mathrm{cm}^{-1}$ could match the Si-O elongation band and the $692 \mathrm{~cm}^{-1}$ band by the Si-O strain band. The band at $906 \mathrm{~cm}^{-1}$ would correspond to vibrations of Al-OH valence, the band at $1540 \mathrm{~cm}^{-1}$ could correspond to muscovite and the band at $1631 \mathrm{~cm}^{-1}$ corresponds to adsorbed water [14]. Normally in the kaolinite spectra we observe four bands relating to four hydroxide groups when the kaolinite is well crystallized and when the Kaolinite is poorly crystallized this reduces to three bands [5] (Figure 4).

By comparing the spectrum of Dolisie with that of mouyoudzi whose kaolinite is the dominant mineral in the range from $3100 \mathrm{~cm}^{-1}$ to $3700 \mathrm{~cm}^{-1}$ (Figure 5 and Figure 6), we find that our Dolisie spectrum shows only two bands of kaolinite instead of four bands we can say that the kaolinite of Dolisie clay is not very crystallized because for a well crystallized kaolinite we have the presence of four (4) bands [5].

\subsection{Differential Thermal and Gravimetric Analysis}

- From ambient to $100^{\circ} \mathrm{C}$, a peak is observed corresponding to a mass loss of $0.9 \%$ caused by the departure of water from the surface of the clay soil of Dolisie.

- From $100^{\circ} \mathrm{C}$ to $300^{\circ} \mathrm{C}$ start of the water adsorbed in the interfoliar space, arranged in 1 or 2 layers corresponding to a mass loss of 1.1\% [15].

- From $300^{\circ} \mathrm{C}$ to $500^{\circ} \mathrm{C}$ corresponds to the loss of mass of $1.5 \%$ of carbonates.

- From $500^{\circ} \mathrm{C}$ to $800^{\circ} \mathrm{C}$ with a mass loss of $3 \%$ corresponds to a departure of water from the kaolinite. This translates to dehydroxylation and leads to the formation of metakaolinite [16]. 


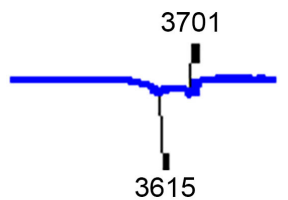

Figure 4. Amplification of the Dolisie infrared spectrum.

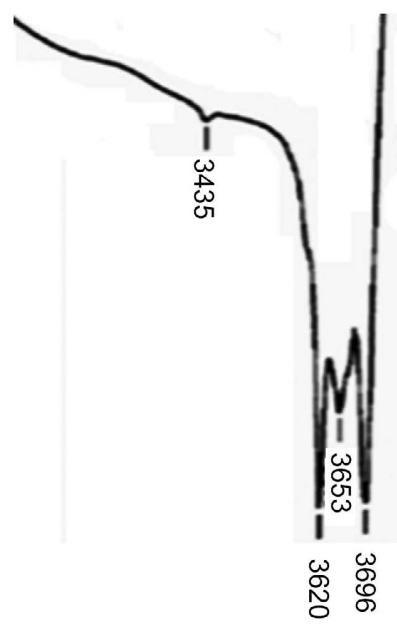

Figure 5. Amplification of the infrared spectrum of Mouyondzi [5].

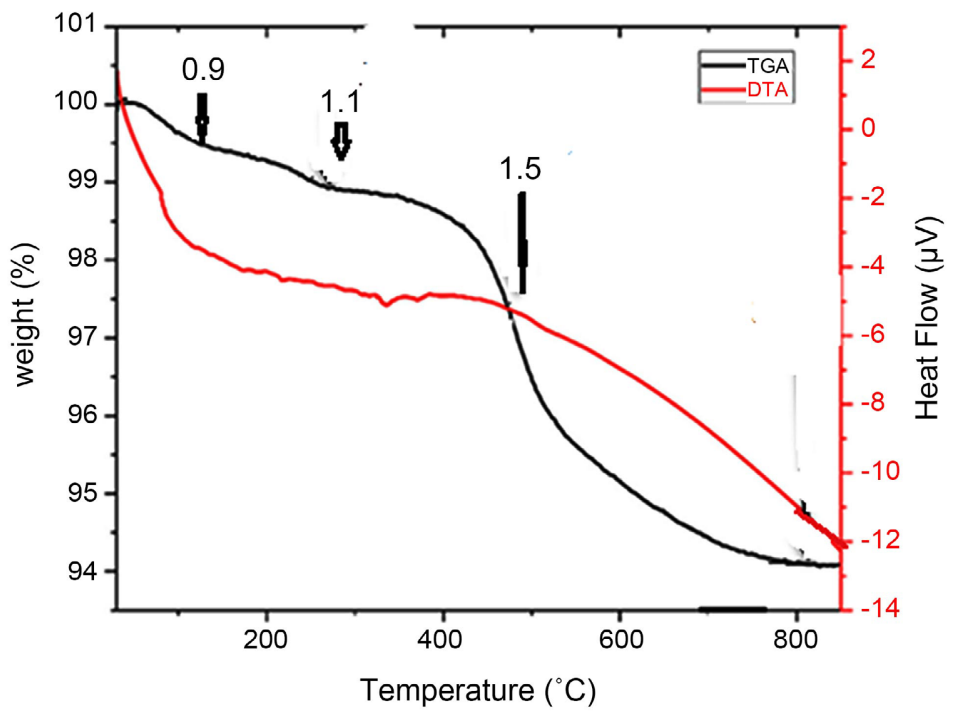

Figure 6. ATG/ATD curve.

\subsection{Chemical Analysis}

Silica and alumina as well as iron oxides are the major constituents in Dolisie clay with levels of $64.72 \%$ and $18.67 \%$ respectively, ie a $\mathrm{SiO}_{2} / \mathrm{Al}_{2} \mathrm{O}_{3}$ ratio equal to 3.46. This value is generally observed in minerals of the kaolinite, illite and montmorillonite type [17]. Other elements ( $\mathrm{Mn}, \mathrm{Ca}$ and $\mathrm{Na}$ ) also appear, but in very small quantities. Dolisie soil has a high $\mathrm{K}_{2} \mathrm{O}$ content (3.37\%), which indicates 
that this clay is probably very rich in illite because the interfoliar space of illites is very rich in potassium [18]. The $\mathrm{Fe}_{2} \mathrm{O}_{3}$ content (3.28), Dolisie's XRD spectrum showed the peaks corresponding to Iron. The $\mathrm{K}_{2} \mathrm{O}$ content is (3.37), the presence of potassium can be justified by feldspars and/or muscovite, the examination of the Dolisie diffractograms made it possible to observe the lines of calcite, magnesite and dolomite (Table 1).

The cation exchange capacity is equal to $3.78 \mathrm{meq} / 100 \mathrm{~g}$. Recall that the CEC of kaolinites is between 3 and $5 \mathrm{meq} / 100 \mathrm{~g}$ and that of illites is between 10 and 40 $\mathrm{meq} / 100 \mathrm{~g}$, the CEC of Dolisie clay is low compared to those of illite and kaolinite (Table 2).

\subsection{Mineralogical Assessment of Dolisie Clay}

The percentages of kaolinite, quartz and dolomite in the Dolisie sample are calculated using the following relationship:

$$
(a)=\sum_{i=1}^{n}\left(M_{i} \cdot P_{i}(a)\right)
$$

Avec:

$T_{a}$ : content (in\%) of element " $a$ " in the material; $T_{a}$ is given by chemical analysis;

$M_{i}$ : content (in\%) of mineral " " in the material and containing the element " $a$ "; $P_{i}(a)$ : proportion of the element " $a$ " in the mineral " $"$ ".

The procedure for calculating the mineralogical balance is such that:

1) Illite is determined from the $\mathrm{K}_{2} \mathrm{O}$ content given by chemical analysis.

2) Kaolinite is determined by the difference between the percentage of $\mathrm{Al}_{2} \mathrm{O}_{3}$ given by chemical analysis and the proportion of $\mathrm{Al}_{2} \mathrm{O}_{3}$ corresponding to illite.

3) Quartz is determined by the difference between the $\mathrm{SiO}_{2}$ content of chemical analysis and the proportions of $\mathrm{SiO}_{2}$ corresponding to kaolinite and illite.

4) Magnesite $\left(\mathrm{MgCO}_{3}\right)$ is calculated from the percentage of $\mathrm{MgO}$ given by the analysis (Table 3).

Table 1. Chemical analysis of Dolisie clay.

\begin{tabular}{cccccccccccccc}
\hline échantillon & $\mathrm{SiO}_{2}$ & $\mathrm{Al}_{2} \mathrm{O}_{3}$ & $\mathrm{Fe}_{2} \mathrm{O}_{3}$ & $\mathrm{MnO}$ & $\mathrm{MO}$ & $\mathrm{CaO}$ & $\mathrm{NaO}$ & $\mathrm{K}_{2} \mathrm{O}$ & $\mathrm{TiO}_{2}$ & $\mathrm{P}_{2} \mathrm{O}_{5}$ & $\mathrm{PF}$ & Total \\
\hline dolisie & 64.72 & 18.67 & 3.28 & 0.00 & 1.11 & $<\mathrm{LD}$ & 0.05 & 3.37 & 1.07 & 0.10 & 6.63 & 99.00 \\
\hline
\end{tabular}

Table 2. Chemical property.

\begin{tabular}{ccccc}
\hline échantillon & $\% \mathrm{C}$ & $\% \mathrm{MO}$ & $\mathrm{CEC}$ & Azote total \\
\hline Dolisie & 0.073 & 0.126 & 3.78 & 0.075 \\
\hline
\end{tabular}

Table 3. Bilan minéralogique.

\begin{tabular}{ccccccc}
\hline échantillon & kaolinite & illite & quartz & anatase & magnésite & hématite \\
\hline Dolisie & 20.51 & 28.08 & 42.44 & 1.07 & 3.83 & 3.28 \\
\hline
\end{tabular}


The mineralogical composition shows that the Dolisie clay consists mainly of quartz (42.44\%) followed by illite (28.08\%) and Kaolinite (20.51\%). The presence of kaolinite and illite in Dolisie's clay allows the latter to be effectively used as a protectant, anti-diarrheal and gastrointestinal [20].

\subsection{Particle Size Analysis}

The Dolisie sample has the following particle size composition: $24.4 \%$ fraction less than $2 \mu \mathrm{m}, 72.7 \%$ fraction between $2 \mu \mathrm{m}$ and $50 \mu \mathrm{m}$ and $2.9 \%$ fraction between $50 \mu \mathrm{m}$ and $2 \mathrm{~mm}$. The fraction of particles between 2 and $50 \mu \mathrm{m}$ in size represents $72.2 \%$ of the sample. These percentages are close to those found in the MY41g, MY45g clays studied by Ms. Djangang [21]. The latter concluded that clays with this particle size could be used in the manufacture of refractory materials. The percentage of particles smaller than $2 \mu \mathrm{m}$ in the Dolisie sample is greater than those of the MY41g and MY45g clays. The rate of sand particles is very low (2.9\%) but fine sand represents $2.5 \%$. Then the sieving of the coarse fraction will not be efficient. The $24.4 \%$ clay, $72.7 \%$ silt and $2.9 \%$ sandy fraction allow us to attribute the clay-silty texture to Dolisie (Table 4, Figure 7).

According to this triangle, Dolisie is found in the zone of soils having a clayey-silty texture, which is in agreement with the particle rates given by the particle size analysis.

Table 4. Shows the Dolisie particle size analysis.

\begin{tabular}{cccccc}
\hline Echantillon & $\begin{array}{c}\text { Argiles } \\
<2 \mu \mathrm{m}\end{array}$ & $\begin{array}{c}\text { Limons fins } \\
(2-20 \mu \mathrm{m})\end{array}$ & $\begin{array}{c}\text { Limons grossiers } \\
(20-50 \mu \mathrm{m})\end{array}$ & $\begin{array}{c}\text { Sables fins } \\
(50-200 \mu \mathrm{m})\end{array}$ & $\begin{array}{c}\text { Sables grossiers } \\
(200-2000 \mu \mathrm{m})\end{array}$ \\
\hline Dolisie & $24.4 \%$ & $62.5 \%$ & $10.2 \%$ & $2.5 \%$ & $0.4 \%$ \\
\hline
\end{tabular}

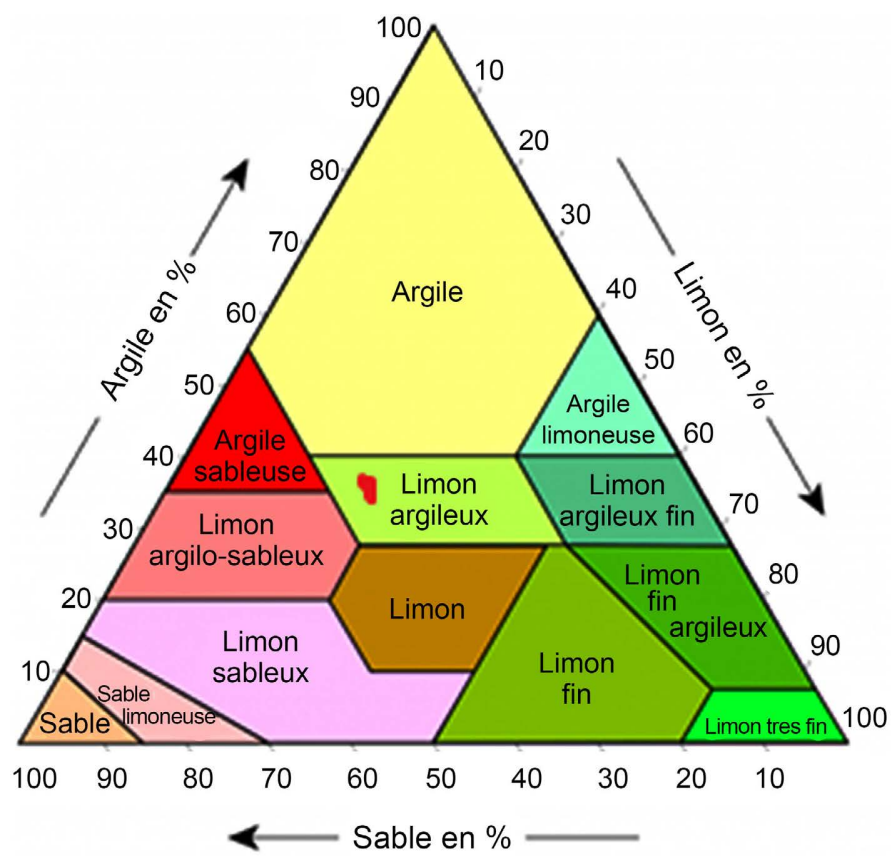

Figure 7. Positioning of Dolisie in the texture triangle. 
The results of the particle size analysis allowed us to position Dol in the Winkler diagram (Figure 8, Figure 9).

\subsection{The Limits of ATTERBERG}

1: Hollow bricks with thin walls. 3-Bricks with vertical perforation.

2: Light block tiles. 4 -Solid bricks.

2 - 4: Low frequency of use.

5 - 9: Average frequency of use.

10 - 24: High frequency of average use.

$>24$ : Very high frequency of use.

The Dolisie sample is in the very low frequency of use area for structural ceramics.

- The ATTERBERG limits obtained allow Dolisie to be placed in the Casagrande abacus. Dolisie.

Depending on the ATTERBERG limits, and using the CASAGRANDE chart, the Dolisie sample exhibits average plasticity and can be considered as a loamy soil with low plasticity. This observation is in perfect agreement with the particle size composition of this sample (loamy soil-clay) (Table 5, Figure 10).

The Bain and Highly workability map allows us to indicate that the Dolisie sample would have moderate drying shrinkage and acceptable molding properties (Figure 11).

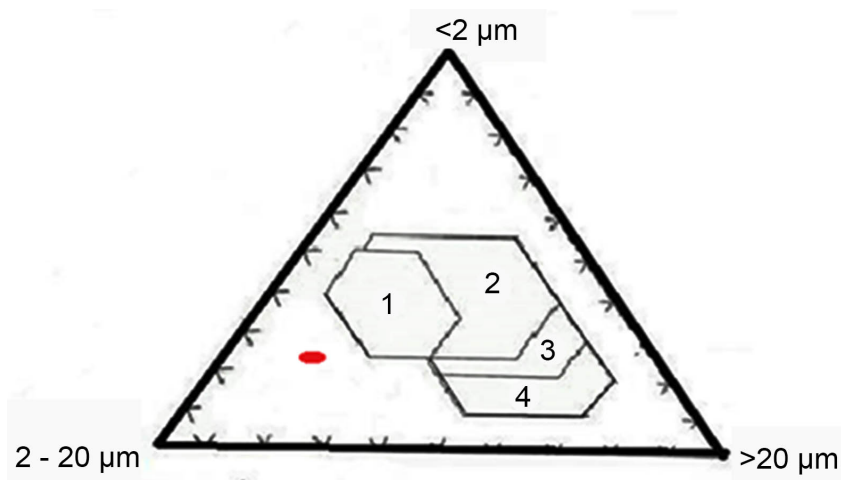

Figure 8. Positioning of Dol in the Winkler diagram.

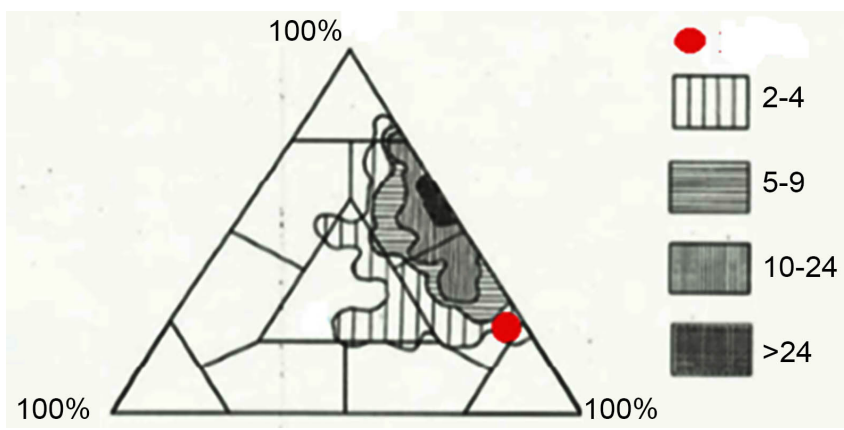

Figure 9. Relationship between frequency of use and texture frequency of use. 
Table 5. ATTERBERG limit of Dolisie.

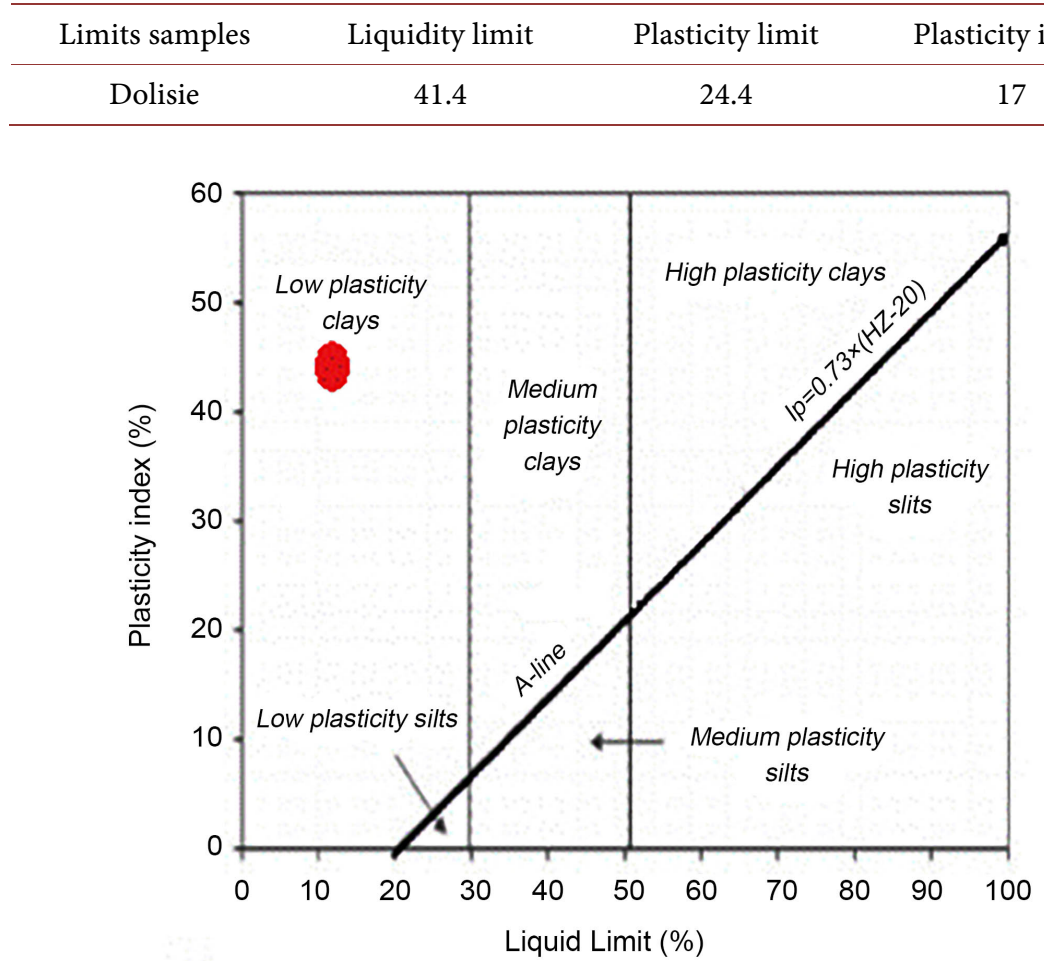

Figure 10. The Abacus of CASAGRANDE.

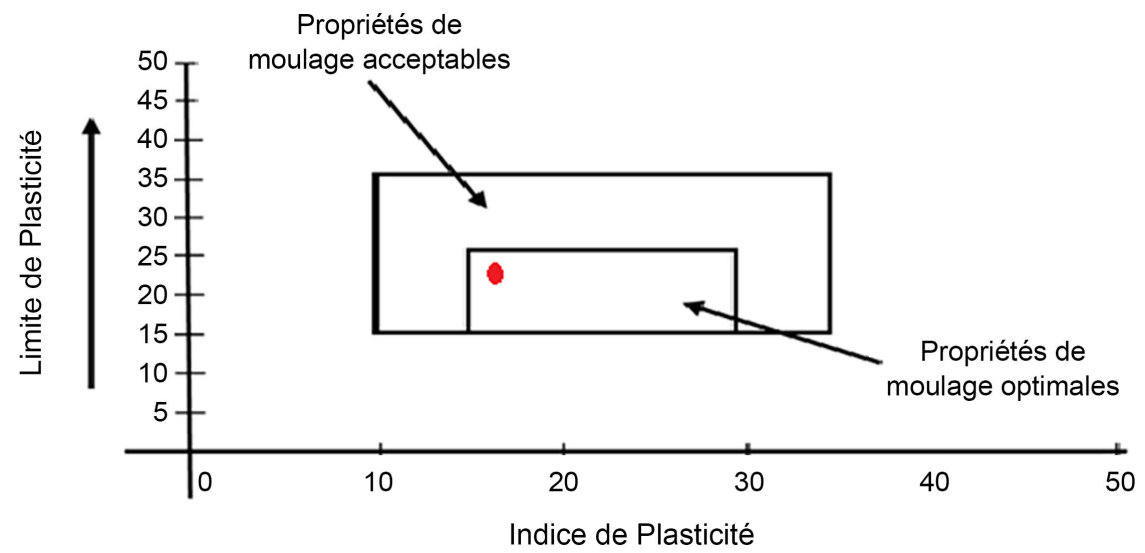

Figure 11. Bain and Highly's workability map.

\section{Conclusions}

The aim of this study was to characterize the clay of the locality of Dolisie in order to enhance it in several areas for this, it was a matter of doing the mineralogical analysis by (DRX, IR, ATG and ATD). Chemical analysis was determined by assaying for oxides by ICP-AES and CEC was determined by the Metson method.

- The geotechnical properties of this soil were determined by the granulometry and the limits of ATTERBERG. These properties made it possible to place this soil in the texture triangle, in the abacus of CASAGRANDE and in the map 
of Bain and Highly. DRX showed the following species: kaolinite, illite, anathase, quartz, muscovite and others, IR showed kaolinite to be poorly crystallized. From ambient to $100^{\circ} \mathrm{C}$, a peak is observed corresponding to a mass loss of $0.9 \%$ caused by the departure of water from the surface of the clay soil of Dolisie.

- From $100^{\circ} \mathrm{C}$ to $300^{\circ} \mathrm{C}$ start of the water adsorbed in the interfoliar space, arranged in 1 or 2 layers corresponding to a mass loss of $1.1 \%$.

- From $300^{\circ} \mathrm{C}$ to $500^{\circ} \mathrm{C}$ corresponds to the loss of mass of $1.5 \%$ of carbonates.

From $500^{\circ} \mathrm{C}$ to $800^{\circ} \mathrm{C}$ with a mass loss of $3 \%$ corresponds to a departure of water from the kaolinite. This translates to dehydroxylation and leads to the formation of metakaolinite. The CEC is 3.78, the granulometric analysis makes it possible to attribute to this soil a clayey-silty texture and the limits of ATTERBERG are: $\mathrm{IL}=41.4, \mathrm{IP}=24.4$ and IP $=17$, the limits of ATTERBERG give this soil a low plasticity. The presence of kaolinite and illite in the clay allows the latter to be effectively used as protectors, anti-diarrheal and gastrointestinal. Analysis showed that silicon, alumina and iron oxides predominate in dolisia clay.

\section{Conflicts of Interest}

The authors declare no conflicts of interest regarding the publication of this paper.

\section{References}

[1] Manea, F., Troquet, M. and Avram, L. (2006) Analyse de certains minéraux argileux utilisés à la préparation desfluides de forage écologiques. Scientific study et Research, No. 3, 689-696.

[2] Djilali, R. (2016) Traitement, caractérisation de l'argile et adsorption des produits polluants pharmaceutiques. Mémoire de master Republique Algérienne Démocratique et populaire, $65 \mathrm{p}$.

[3] Moutou, J.M., Mbedi, R., Elimbi, A., Njopwouo, D., Yvon, J. and Odile Barres Ntekela, H. (2012) Mineralogy and Thermal Behaviour of the Kaolinitic Clay of Loutété (Congo-Brazzaville). Research Journal of Environmental and Earth Sciences, 4, 316-324.

[4] Moutou, J.M., Diamouangana, Z.F.M., Ossebi, J.G., Foutou, P.M. and Bibila, J.C. (2017) Mineralogical and Physicochemical Characterization of the Clay Soil in the Locality of Loukolela (Congo). Research Journal of Environmental and Earth Sciences, 9, 14-23. https://doi.org/10.19026/rjees.9.5298

[5] Moutou, J.M., Foutou, P.M., Matini, L., Banzouzi samba, V., Diamouangana Mpissi, Z.F. and Loubaki, R. (2018) Characterization Mouyondzi Clay. Journal of Minerals and Materials and Engineering, 6, 119-138. https://doi.org/10.4236/jmmce.2018.61010

[6] Moutou, J.M., Loubaki, R., Nsongo, T. and Foutou, P.M. (2019) Characterization and Technological Properties of Two Clay Soils in Republic of Congo. Research Journal of Material Sciences, 7, 1-10

[7] Makosso Voula, R., Diamouangana Mpissi, F.Z., Moutou, J.M., Banzouzi Samba, V.I., Foutou, P.M. and Ngoma, J.P. (2021) Characterization and Valuation of a Clay soil Sampled in Londela-Kayes in the Republic of Congo. Research Journal of minerals and Material Characterization and Engineering, 9, 117-133. https://doi.org/10.4236/jmmce.2021.92009 
[8] Carignan, J., Hild, P., Mevelle, G., Morel, J. and Yeghicheyan, D. (2001) Routine Analyses of Trace Elements in Geological Samples Using Flow Injection and Low Pressure On-Line Liquid Chromatography Coupled to ICP-MS: A Study of Geochemical Reference Materials, BR, DR-N, UB-N, AN-G and GH. Geostandards Newsletter, 25, 187-198. https://doi.org/10.1111/j.1751-908X.2001.tb00595.x

[9] Association Française de Normalisation (AFNOR) (1999) AFNOR NFX31-130. Soil Quality-Chemical Methods-Determination of Cationic Exchange Capacity (CEC) and Extractible Cations. Association Française de Normalisation, Paris.

[10] International Organization for Standardization (ISO) (1995) NF ISO10694: Soil Quality Determination of Organic and Total Carbon after Dry Combustion (Elementary Analysis).

[11] Association Française de Normalisation (AFNOR) (1984) AFNOR NF X 31-107. Granulats Dans: Recueil des normes françaises du bâtiment et Constituants du béton, tome 3, 2nd Edition, Association Française de Normalisation, Paris, 78-80.

[12] Rakotorina, J.A. (2010) Essai de stabilisation des routes en terre par l'utilisation d'émulsion polymère: Cas de latérite de VONTORONA. Mémoire de fin d'étude, Université d'Antananarivo, Tananarive, 97.

[13] Boch, P. (2001) Matériaux et processus céramiques, Édition HERMES, Paris, 285 p.

[14] Ndjioumou, C. (2007) Caractérisations et utilisation dans l'élaboration des minéraux réfractaires. Université de Yaoundé I, Yaoundé, 119

[15] Fayza, G.B. (2007) Matériaux de mullite à microstructure organisée composés d'assemblages muscovite-Kaolinite. Thèse de doctorat, Université de Limoges, Limoges.

[16] Trubaca Boginska, A., Adina, R., Vaivars, G. and Svirksts, J. (2018) A Study on Acidification and Intercalation of Illite Clay Minerals and Their Potential Use as a Filler in Speek Composite Membranes. Key Engineering Materials, 762, 186-191. https://doi.org/10.4028/www.scientific.net/KEM.762.186

[17] Assifaoui, A. (2002) Etude de la stabilité des barbotines à base d'argiles locales: Application aux formulations céramiques industrielles. Doctorat, Université Hassan II, Casablanca, 140 p.

[18] Traore, K. (2003) Frittage à basse température d'une argile Kaolinitique du Burkina Faso, Transformation thermiques et réorganisation structurales. Thèse de Doctorat, Université de Limoges, 209 p.

[19] Traore, K. (2003) Frittage à basse température d'une argile Kaolinitique du Burkina Faso, Transformation thermiques et réorganisation structurales. Thèse de Doctorat, Université de Limoges, Limoges, 209 p

[20] Gomes, C.S.F. and Silva, J.B. (2007) Minerals and Clay Minerals in Medical Geology. Applied Clay Science, 36, 4-21. https://doi.org/10.1016/j.clay.2006.08.006

[21] SITA (2010) propriétés chimiques de quelques sols argileux Congolais mémoire pour l'obtention du diplôme de capes ENS. 